Scientific Journal Warsaw University of Life Sciences - SGGW

Problems of World Agriculture volume 17 (XXXII), number 4, 2017: 292-301

DOI: $10.22630 /$ PRS.2017.17.4.105

Joanna Smoluk-Sikorska ${ }^{1}$

Poznan University of Life Sciences

\title{
Distribution of Organic Food in Poland
}

\begin{abstract}
Distribution of organic food in Poland has a number of weaknesses resulting from low and irregular supply as well as dispersion of producers and intermediaries. The paper presents the outcomes of research carried out in 2012 in three types of retail outlets offering organic food, i.e. specialist shops, groceries and retail networks. The investigation was conducted in the form of indepth interviews using a standardised questionnaire. As the research shows, only in specialist stores does the product range satisfy consumer needs, whereas in the other outlets it is limited generally to processed products. Wholesalers, organic farms and brokers are the main providers of the surveyed retail outlets; nevertheless, specialist shops use the services of more providers than the other types of outlets. Low supply of organic food results in high retail prices. Specialist shops and groceries apply margins up to $40 \%$ on average, while retail networks have margins up to $20 \%$.
\end{abstract}

Key words: organic food, distribution, retail, product range, supply sources, price level, Poland

JEL Classification: D22, M31, Q13

\section{Introduction}

Organic farming is one of the key elements of sustainable development. Opposite to intensive agriculture, based mainly on economic goals, it harmoniously links environmental with economic and social aims (Chmielak, 2000). In Poland, there are suitable conditions for development of organic production methods, mostly because of low chemicalization of agriculture. This system is more labour consuming than conventional farming, and therefore it fosters maintenance of workplaces in rural areas. Furthermore, price premiums for organic produce and subsidies to organic areas contribute to growth of farmer incomes.

Although organic farming in Poland has been developing since the early 1990s, a significant growth in this field occurred in 2004, when Poland entered the EU and organic farmers got the opportunity to use the support in the framework of the agro-environmental programmes. Afterwards, the organic areas increased significantly. In 2016, there were 22,435 organic farms and the organic area amounted to 537 thousand ha (Zdrojewska, 2017). Currently, Poland takes fifth place in Europe when it comes to organic area and the sixth place in terms of number of producers (Willer and Lernoud, 2017).

High dynamics of growth in organic areas has not induced the expected supply volume increase. Some of the converted farms do not deliver produce to the market. Moreover, one problem of organic food distribution is the fact that farms are dispersed all over the country and the efficient flow of goods is very difficult (Żakowska-Biemans and Gutkowska, 2003). Therefore, direct selling has dominated in distribution of organic food, which is typical for countries with low levels of market development. Recently indirect distribution channels, particularly specialist shops, grocery outlets and retail networks, have been becoming more

${ }^{1}$ PhD, Department of Economics PULS, ul. Wojska Polskiego 28, 60-637 Poznań, e-mail: smoluk@up.poznan.pl 
and more important. Nevertheless, they are slightly identified; thus, there is a need to investigate indirect forms of distribution.

The main objective of the paper is to recognise and discuss the state and factors influencing the organic food distribution in Poland. The specific objectives concern the recognition of the width and depth of product range, determining supply sources of the outlets offering organic food, discussion on the problems occurring in the distribution sphere as well as prices of organic food.

\section{Material and Methods}

As was mentioned before, the organic food market in Poland is small and characterised by low transparency. Its participants hardly have access to information on production, sale or level and diversification of prices; therefore, it is necessary to investigate deeply this sphere. Distribution is of particular importance, because it has significant influence on profitability of organic farms and functioning of the entire market. For that reason, it is necessary to identify the main elements and the state of market development.

In order to achieve this goal, in 2012 research on retail outlets dealing with organic food was undertaken. The investigated units were located in the eight largest agglomerations in Poland (Table 1). The research had the form of an inquiry based on a standardised questionnaire (PAPI method), conducted by trained interviewers. The surveyed units were chosen using purposive selection. Each of them offered at least three different product groups of organic food. The investigation covered 131 specialist shops, 109 general grocery stores and 179 units of retail networks. The collected data was coded and processed in an Excel environment. The results were presented and discussed with the use of descriptive statistics instruments.

Table 1. Distribution of the investigated outlets

\begin{tabular}{l|cccccc}
\hline \multirow{2}{*}{ Agglomeration } & \multicolumn{2}{|c}{ Specialist shops } & \multicolumn{2}{c}{ Grocery outlets } & \multicolumn{2}{c}{ Retail networks } \\
\cline { 2 - 7 } & Amount & Share (\%) & Amount & Share (\%) & Amount & Share (\%) \\
\hline Warszawska & 29 & 22.1 & 26 & 23.9 & 43 & 24.0 \\
Górnośląska & 23 & 17.6 & 21 & 19.3 & 31 & 17.4 \\
Krakowska & 19 & 14.5 & 17 & 15.6 & 25 & 14.0 \\
Poznańska & 16 & 12.1 & 13 & 11.9 & 21 & 11.7 \\
Gdańska & 14 & 10.7 & 10 & 9.2 & 18 & 9.5 \\
Wrocławska & 12 & 9.1 & 9 & 8.2 & 17 & 10.0 \\
Lódzka & 9 & 6.9 & 7 & 6.4 & 14 & 7.8 \\
Szczecińska & 9 & 6.9 & 6 & 5.5 & 10 & 5.6 \\
Total & 131 & 100 & 109 & 100 & 179 & 100 \\
\hline
\end{tabular}

Source: author's own research.

The research was funded by the Polish Ministry of Science and Higher Education within the research project No NN112 385440 "State and Condition of the Development of the Organic Food Retail". 


\section{The Main Organic Food Distribution Channels}

For years, direct selling to individual consumers has been the most important distribution channel on the Polish organic food market, because it generates lower costs and margins, due to which it is possible to offer products at competitive prices (Czubała, 2001). However, a disadvantage of this form of selling is the fact that it occurs only on rural areas. Currently, consumer studies show that specialist shops and supermarkets are the basic supply sources in organic food. Other forms are of little importance (Pilarczyk and Nestorowicz, 2010; Łuczka-Bakuła and Smoluk-Sikorska, 2011).

Meanwhile, in Western countries, organic food has emerged as an important segment of retailing in recent years. The organic food industry has moved from niche to mainstream markets (Jones et al., 2001). The most organic produce is sold through supermarkets. The market share of retail networks in total sale of organic food is in the range between $60 \%$ and $90 \%$ in Austria, Belgium, Croatia, Czech Republic, Luxembourg, and the UK. Meanwhile, in Italy, France, Germany and the Netherlands the share ranges between $40 \%$ and $60 \%$, because in these countries traditional organic retailers, mostly specialist shops, are still important market players (Organic in Europe, 2016).

The advantage of the supermarkets is that they sell at lower prices, offer a wide product range, have sufficient space, good equipment and may carry out promotion actions (Richter and Hempfling, 2003; Pilarczyk and Nestorowicz, 2010). In turn, a narrow and shallow product range that results in an incomplete selection, low environmental awareness and knowledge of organic food among the selling staff, may be recognised as their downsides (Doležalova et al., 2009).

According to Richter and Hempfling (2003), there are three types of supermarkets on the organic food market:

- $\quad$ supermarkets with a maximal strategy, offering more than 400 organic products and who engage in their promotion,

- $\quad$ supermarkets with a basic strategy (between 50 and 250 organic products),

- $\quad$ supermarkets with minimal strategy (less than 50 organic products).

If the retail chains take the risk and start to engage in organic farming using maximal strategy in countries with emerging markets, like Tesco and Sainsbury in the UK in the 1990s, they will probably gain the largest market share (Atănăsoaie, 2011). However, supermarkets require assured supplies of homogenous quality and large volumes. This poses a problem because in these countries, organic food is produced in rather small quantities. In terms of the small size of the industry, the resources of supply are limited and unstable. Therefore, large retail networks very often import organic food, which results in relatively higher prices (Wier and Calverly, 2002).

Nevertheless, in countries with a less developed market, the largest share of organic food is still sold thorough specialist shops (Atănăsoaie, 2011). Specialist shops are important for consumers, who expect close contact with salespersons. They require from the staff full information on organic products. Furthermore, specialist retailers conduct educational activities and play a role as communicators. They have to be innovative and develop new concepts, so that they can assure a wide product range and attract new clients, in order to compete with retail networks (Santucci et al. 1999).

In Poland, the number of specialist shops is estimated at over 500. Currently, in cities, one observes a growth of units dealing solely with organic food, offering over 1000 
products. These are generally self-service stores that satisfy consumer needs, but they sell at higher prices than supermarkets. Therefore, recently this retail form, as well as groceries, have been becoming more and more active players on the organic food market.

\section{Product Range}

The key actions in running a commercial activity are decisions on the product range (Szulce, 1998). As the research shows, specialist shops have a much wider selection - 57\% of the units sold over 200 different organic products. Over 3/4 of grocery shops offered up to 100 products, which proves that generally organic food supplements their basic assortment. When it comes to the retail networks, between 200 and 300 organic products were available in nearly $44 \%$ of the surveyed outlets. It indicates that these are the supermarkets with basic strategy according to the classification proposed by Richter and Hempfling (2003).

Concerning the width of the assortment, the most specialist shops offered cereal products, fruit and vegetables products, dairy products as well as spices. In turn, in the groceries, cereal products, fruit and vegetable products could be found in the assortment, whereas mainly processed products were available in the retail networks (Table 2). Only a few of those outlets offered fresh products, i.e. vegetables, fruit and meat products and none of them offered fresh meat. Such product range is a result of organic food processing in Poland, because the majority of companies deal with cereals, fruit and vegetables (in 2016 $-17.2 \%$ and $31.1 \%$ ), while only $6.1 \%$ with meat (Zdrojewska, 2017). Underdevelopment of this part of the market causes shortages, because currently the consumer interest in organic meat has been growing (Łuczka-Bakuła, 2007).

Table 2. Product range in the investigated outlets

\begin{tabular}{l|ccc|ccc}
\hline \multirow{2}{*}{ Product group } & \multicolumn{3}{|c|}{$\begin{array}{c}\text { Share of outlets offering } \\
\text { a given product group (\%) }\end{array}$} & \multicolumn{3}{c}{$\begin{array}{c}\text { Average number of offered products } \\
\text { in given product groups }\end{array}$} \\
\cline { 2 - 7 } Bread & 1 & 2 & 3 & 1 & 2 & 3 \\
Cereal products & 69.0 & 20.2 & 47.5 & 12.7 & 3.0 & 4.2 \\
Fruit & 72.6 & 95.4 & 83.4 & 40.4 & 32.9 & 37.3 \\
Vegetables & 65.5 & 51.4 & 12.1 & 15.1 & 6.8 & 5.3 \\
Fruit products & 65.5 & 27.5 & 17.4 & 18.2 & 7.2 & 6.7 \\
Vegetable products & 67.9 & 77.1 & 73.7 & 29.8 & 8.3 & 15.3 \\
Spices & 67.9 & 71.6 & 83.2 & 29.4 & 10.0 & 24.7 \\
Oils & 69.0 & 70.6 & 45.3 & 42.5 & 21.8 & 9.4 \\
Dairy products & 67.9 & 80.7 & 63.4 & 18.1 & 6.5 & 12.1 \\
Eggs & 67.9 & 32.1 & 31.3 & 23.4 & 5.6 & 11.3 \\
Sausages & 69.0 & 51.4 & 89.4 & 3.4 & 2.1 & 1.7 \\
Meat & 40.5 & 22.9 & 8.7 & 19.4 & 4.6 & 3.4 \\
Coffee, tea & 31.0 & 9.2 & - & 10.0 & 5.0 & - \\
Sweets & 67.9 & 70.6 & 43.2 & 29.6 & 16.9 & 7.8 \\
\hline
\end{tabular}

1-specialist outlets; 2-general grocery stores; 3-retail networks.

Source: author's own research. 
The distributors are aware that organic food accessibility is insufficient. Almost $70 \%$ of the investigated specialist and grocery outlets claimed that sometimes there is a lack of particular wanted products. According to every fifth specialist retailer, their selection completely satisfies consumer needs, whereas in over $1 / 3$ of grocery outlets, often or very often there is a lack of certain wanted products. This indicates the need for widening the product range within certain food groups, in those cases where there are shortages - for instance, meat.

The study proves that retailers tried to satisfy client needs and therefore about $3 / 4$ of specialist shops and $1 / 4$ of groceries made individual orders for customers. This question was not directed to the retail networks, because they do not provide individualised customer service. In turn, they were asked if the assortment of organics is sufficient in the investigated unit and in $73.4 \%$ of cases, the answer was positive. This results from the fact that customers of these outlets mostly purchase conventional food and occasionally decide to buy organic food.

A positive fact is that almost $93 \%$ of specialist shops, over $60 \%$ of general grocery stores and $56 \%$ of units of retail networks aim to widen their product range in future; however, it depends on particular factors, such as demand growth, price decrease and wider selection of suppliers.

\section{Supply Sources}

The purchase of goods is one of the basic functions of a trading company. It requires assuring deliveries of goods appropriately in terms of type, quantity, time, place and quality to demand, including stock policy (Sławińska, 2002). These factors determine the need for searching for alternative supply sources. On the organic market a retailer has two ways of supply: directly from the producer or through intermediaries. The average number of suppliers for a specialist shop amounted to about 24, while groceries had 4 .

A significant obstacle for organic market development is the fact that the wholesale industry is still underdeveloped (Table 3). Organic food wholesalers are very often local microenterprises and some of them do not have appropriate equipment to assure complete selections of fresh produce. Moreover, organic food has features of innovative products, which influences the fact that indirect chains are not willing to assume the risk of introducing them to the market.

According to the investigated retailers, the strongest advantage of wholesale purchases in is a broader selections, which results mainly from the fact that farmers, compared to wholesalers, deliver only selected products. Those surveyed recognize that the possibility of placing an order is a very important attribute of wholesale purchased. The retailers claim that wholesalers should engage more in gaining market information or carrying out consumer studies. They also ought to participate in promotion of organic food, also through collaboration with retail chains, e.g. through organizing common group advertisements that would allow for dividing advertising costs on more enterprises (Pilarczyk, 1999).

Farms were the second important source of supply for retail stores. The most essential advantages of these purchases were product freshness, maintaining collaboration with 
farmers and contracts to guarantee regularity of supply, and the possibility to negotiate favourable price conditions.

Processors (fruit and vegetable processing companies, cereal processing companies, bakeries, butchers, etc.) are quite an important group of providers, especially for retail networks and specialist shops. A downside of this kind of supply source is dispersion of the enterprises and related to this - distance. On one hand, in the case of cereal processing companies, the distance is shorter because there are more of them, and on the other hand, the smaller number of butchers makes direct purchase difficult. When it comes to large retail networks the situation is different, because they are able to assure fast and elastic transportation of goods, both fresh and processed; nevertheless, they do not deal with organic meat and its products. Particular supermarkets purchase thorough producer groups, because they guarantee stable conditions and regular deliveries of high quality products.

Brokers are also quite important providers of the surveyed specialist shops. Brokers accept orders, create client databases, and collaborate with customers regarding volume and frequency of deliveries as well as gather information on market demand. They also cooperate with producers by carrying out specialized trainings and enable establishing trade contacts as well as entering new market segments. Brokers usually charge lower commissions compared to wholesale margins (Czubała, 2001). Due to their contacts with a number of producers, they contribute to diversification of the product range available on the market, which has particular meaning in the case of organic food.

Table 3. Supply sources of the inquired outlets (\%)

\begin{tabular}{|c|c|c|c|c|c|c|c|c|c|c|c|c|c|}
\hline \multirow[t]{2}{*}{ Product } & \multicolumn{2}{|c|}{ Farm } & \multicolumn{3}{|c|}{ Wholesaler } & \multicolumn{3}{|c|}{$\begin{array}{l}\text { Processing } \\
\text { company }\end{array}$} & \multirow{2}{*}{$\begin{array}{c}\begin{array}{c}\text { Farmers' } \\
\text { market }\end{array} \\
1\end{array}$} & \multicolumn{2}{|c|}{ Broker } & \multicolumn{2}{|c|}{$\begin{array}{c}\text { Producers' } \\
\text { group }\end{array}$} \\
\hline & 1 & 2 & 1 & 2 & 3 & 1 & 2 & 3 & & 1 & 2 & 1 & 3 \\
\hline Bread & 43.4 & 23.8 & 38.2 & 50.0 & 47.3 & 25.0 & 26.2 & 54.9 & - & 9.2 & 11.9 & 3.0 & - \\
\hline $\begin{array}{l}\text { Cereal } \\
\text { products }\end{array}$ & 27.8 & 10.6 & 83.5 & 100 & 76.5 & 16.5 & - & 34.7 & - & 17.7 & 10.6 & - & 23.4 \\
\hline Fruit & 68.9 & 35.7 & 54.1 & 64.3 & 87.5 & - & - & - & 1.4 & 6.8 & - & - & 17.8 \\
\hline Vegetables & 74.7 & 55.6 & 54.7 & 44.4 & 78.4 & - & - & - & 1.3 & 6.7 & - & - & 23.6 \\
\hline $\begin{array}{l}\begin{array}{l}\text { Fruit } \\
\text { products }\end{array} \\
\end{array}$ & 20.0 & 6.7 & 71.3 & 87.6 & 65.1 & 22.5 & 19.1 & 34.6 & - & 20.0 & - & - & 36.3 \\
\hline $\begin{array}{l}\text { Vegetable } \\
\text { products }\end{array}$ & 25.0 & 8.2 & 72.5 & 76.7 & 73.4 & 21.3 & 23.3 & 45.7 & - & 20.0 & - & - & 28.1 \\
\hline Spices & 8.8 & - & 85.0 & 100 & 67.4 & 16.3 & - & 23.4 & - & 8.8 & 6.1 & - & 11.3 \\
\hline Oils & 15.0 & 13.3 & 85.0 & 80.7 & 85.3 & 26.3 & - & 37.5 & & 7.5 & 6.0 & - & \\
\hline $\begin{array}{l}\text { Dairy } \\
\text { products }\end{array}$ & 44.3 & 57.1 & 54.4 & 42.9 & 45.7 & 22.8 & 57.1 & 68.3 & - & 10.1 & - & 6.0 & \\
\hline Eggs & 86.1 & 82.1 & 27.8 & 35.7 & 87.3 & 2.5 & 8.9 & & 1.3 & 5.1 & - & - & 17.4 \\
\hline Sausages & 27.3 & - & 40.9 & 40.0 & - & 43.2 & 60.0 & 100 & - & 4.5 & - & - & - \\
\hline Meat & 35.3 & - & 41.2 & - & - & 41.2 & 100 & - & - & 2.9 & - & - & - \\
\hline Coffee, tea & - & - & 94.9 & 93.5 & 67.8 & 11.4 & - & 56.3 & - & 15.2 & 6.5 & - & - \\
\hline Sweets & - & - & 96.0 & 90.5 & 87.4 & 12.0 & 19.0 & 35.6 & - & 14.7 & - & - & - \\
\hline
\end{tabular}

1-specialist outlets; 2-general grocery stores; 3-retail networks.

Source: author's own research. 
Only every $10^{\text {th }}$ inquired retailer collaborated with providers, mainly with farmers. This collaboration included contracts on deliveries of products. Retail networks offered similar agreements. Such a purchase system guarantees delivery of the required type and quality of products and reduces the risk of shortages (Szczepankiewicz, 2004).

As was mentioned before, one of the most important limitations of the efficient supply of retail outlets in organic food is dispersion of providers. The basic means of transportation is cost-consuming motor transportation. According to research, the average distance from the investigated specialist shops to wholesalers amounted to nearly $146 \mathrm{~km}$, whereas to general grocery shops almost $160 \mathrm{~km}$ (Table 4). The distance to brokers was shorter (respectively 75 and $50 \mathrm{~km}$ ), which results from the fact that they deliver goods to places where the demand occurs.

Table 4. The distance between retail outlets and suppliers

\begin{tabular}{|c|c|c|c|c|c|c|c|}
\hline \multirow{3}{*}{ Supplier } & \multicolumn{2}{|c|}{ Distance $(\mathrm{km})$} & \multicolumn{5}{|c|}{ Who covers the transportation cost $(\%)$} \\
\hline & \multirow{2}{*}{1} & \multirow{2}{*}{2} & \multicolumn{2}{|c|}{ Supplier } & \multicolumn{2}{|c|}{ Outlet } & \multirow{2}{*}{$\begin{array}{c}\text { Commonly } \\
1\end{array}$} \\
\hline & & & 1 & 2 & 1 & 2 & \\
\hline Wholesaler & 145.9 & 159.1 & 39.7 & 48.8 & 50.9 & 51.2 & 9.4 \\
\hline Broker & 75.7 & 50.0 & 10.0 & 50.0 & 75.0 & 50.0 & 15.0 \\
\hline $\begin{array}{l}\text { Processing } \\
\text { company }\end{array}$ & 169.7 & 52.4 & 30.3 & 80.8 & 51.5 & 19.2 & 18.2 \\
\hline Farmer & 101.4 & 76.0 & 36.6 & 77.1 & 56.1 & 22.9 & 7.3 \\
\hline
\end{tabular}

1-specialist outlets; 2-general grocery stores.

Source: author's own research.

Quite significant differences were observed in the distance to processors $(170 \mathrm{~km}-$ specialist outlets and $52 \mathrm{~km}$ - groceries). Processors supply groceries generally when they are located in the neighbourhood of an outlet. Similar dependence arises with deliveries from farms - they were located $101 \mathrm{~km}$ away from specialist shops and $76 \mathrm{~km}$ away from grocery outlets. Usually farmers were responsible for the transportation to the surveyed shops. This further distance between specialist shops and suppliers, compared to groceries, generally resulted from the necessity to assure a differentiated product range as well as the need to search for suppliers offering a diverse assortment. In the case of retail networks, the situation is different, because the purchase is usually made for the entire network from wholesalers which are between 20 and $70 \mathrm{~km}$ distant, and processing companies located 15 $300 \mathrm{~km}$ away from the supermarket.

\section{Prices of Organic Food}

The relatively high price level of organic food in Poland results from low and irregular supply. The price premiums are relatively high and differentiated. They range from a dozen in vegetables and cereal products, to even 600 hundred percent in the case of olive oil and other processed products (Łuczka Bakuła and Smoluk-Sikorska, 2011).

Immaturity of the Polish organic market and its weak recognition contributes to the fact that in the process of pricing, it is not possible to take into account a number of factors of market character (e.g. demand or competition). Factors specific for the market in the 
initial stage of growth have the highest influence on price for organic food. In the process of pricing, the cost method dominates in the inquired shops. Only small a part of those surveyed declared the use of methods based on demand or competitor observation (Fig. 1).

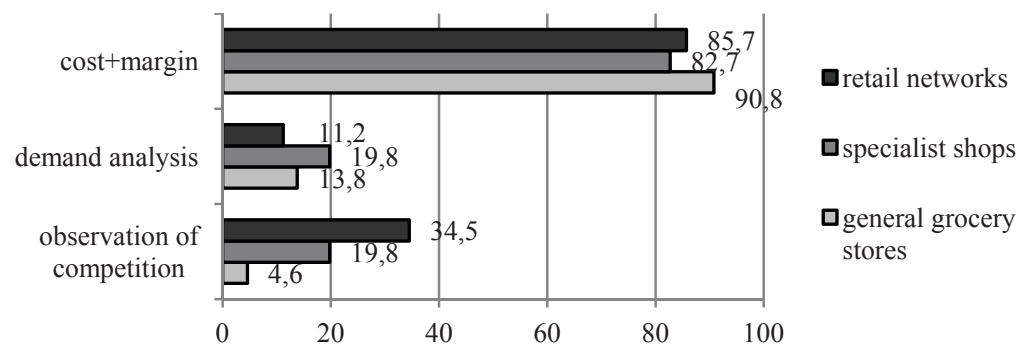

Fig. 1 Methods of pricing in the investigated outlets (\%)

Source: author's own research.

One of the most important determinants of price is margin level. The functioning of the trade margin system in specialist shops or at specialist wholesalers depends mainly on freedom in establishing margin rates and the strategy adopted by the company. Margins are also influenced by such factors as turnover, range of performed trade functions and their costs as well as elasticity of demand (Rogoda, 2003). Higher margins are applied in cities and shopping centres, where the operational costs are relatively high. In turn, the margins are lower in local stores in smaller towns. Large retail networks, in relation to high turnover and economies of scale, also apply smaller margins.

The investigated specialist and grocery shops (over 60\%) usually apply margins between $21 \%$ and $40 \%$. This covers operational costs and allows to maintain demand quantity assuring sufficient turnover. Nonetheless, one should notice that margins on organic products in specialist shops are higher in relation to the business specifics of the outlet, which includes employing qualified staff, service and consulting. In turn, retail networks declared margin up to $20 \%$.

Retail margins have a greater share in price on less durable products requiring special storage devices, i.e. meat, sausages or eggs (Fig. 2). For products with lower storage requirements, the margin share is smaller. Margins are also lower for products with high demand, i.e. vegetables, fruit, dairy or bread. Definitely, higher margin levels for all product groups occurred in specialist shops. Higher margins indicate that the outlets apply a high-price strategy, but also that they have high operational costs.

In the retail networks, the margin level was lower according to the applied low-price strategy. Moreover, the customers of retail networks have lower incomes; therefore, too high margins would result in lowered demand. 


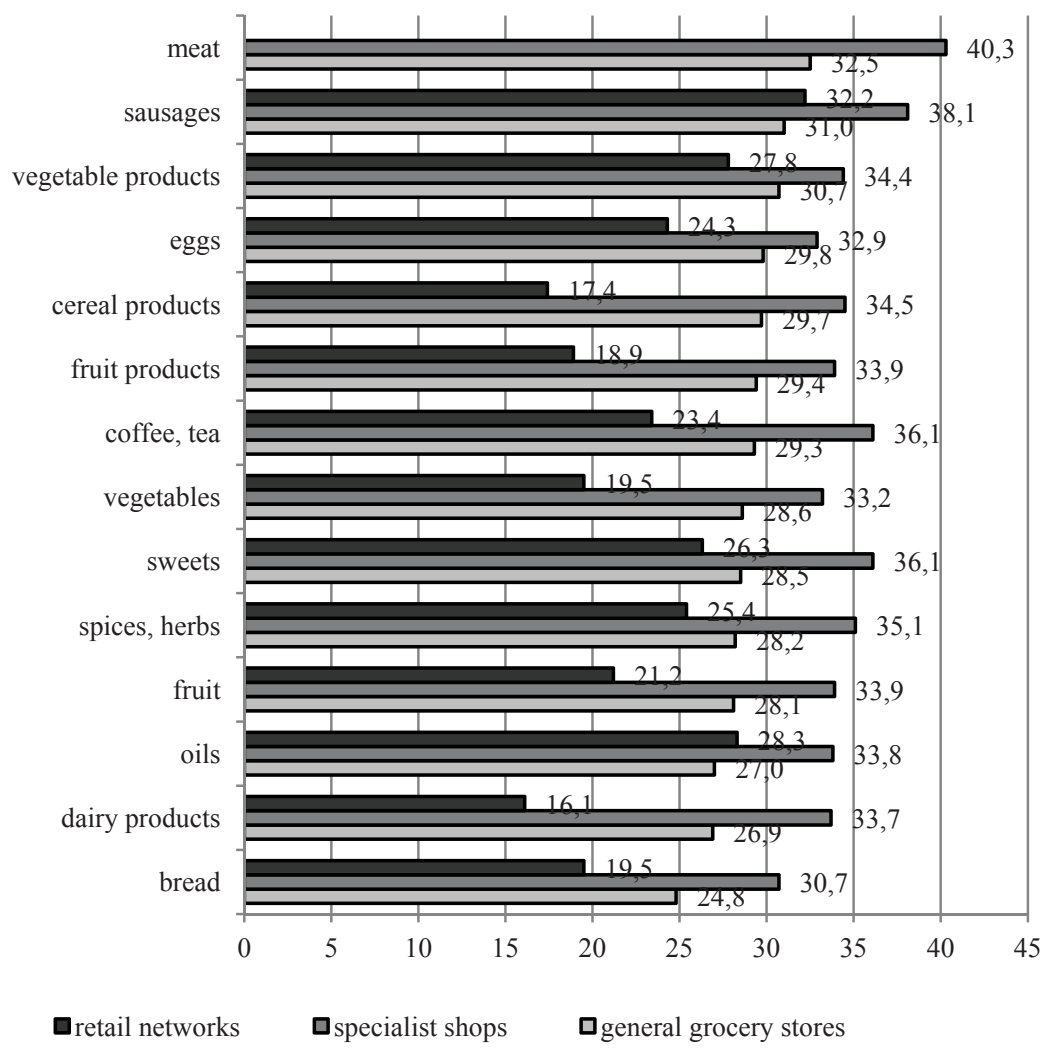

Fig. 2. Declared margin level on particular products (\%)

Source: author's own research.

When it comes to Polish consumers, price is the main determinant of demand for organics, unlike in Western European countries, where non-price determinants are more important. It is highly probable that in future, as the Polish market develops, such factors as quality or uniqueness of products will be more effectual.

\section{Conclusions}

As shown by the research, the indirect organic food distribution channels in Poland come to specialist shops with increasing significance of groceries and retail networks. The selection of organic food, especially in outlets of retail networks, consists of processed products with longer expiration terms. The product range lacks fruit, vegetables and meat (it is respectively offered by none, $12 \%$ and $17 \%$ of supermarkets), which are of high consumer interest. In turn, the amount of specialist shops is insufficient to satisfy consumer expectations. Dispersion of supply sources and high price levels are significant problems of the distribution sphere as well. An incomplete selection of providers results in the necessity 
for purchasing from a number of different supply sources (even over 20 in the case of specialist shops), which shifts the transaction cost. The most important providers for specialist shops and groceries are wholesalers, farms and processing companies, whereas for supermarkets - wholesalers and processing companies. An additional problem is that the supply sources are quite distant from the surveyed outlets - wholesalers about $150 \mathrm{~km}$ from specialist shops and groceries and in the case of farms - respectively over 100 and 76 $\mathrm{km}$. Therefore, the research results show that despite some improvement, the trade availability of organic food is still limited.

Development of the organic food market and simultaneously of distribution requires engagement and common undertakings from its participants. Support from public institutions and strong market players would influence the functioning of the market. In addition, vertical integration of larger units, small specialist shops and wholesalers would allow improvement of the assortment selection, entrance to new markets and gain larger groups of consumers.

\section{References}

Agricultural and Food Quality Inspection (2017). Raport o stanie rolnictwa ekologicznego w Polsce w latach 2015-2016. GIJHARS, Warszawa.

Atănăsoaie, G. (2011). Distribution on the organic foods markets. Journal of Horticulture Forestry and Biotechnology, 15(3), 19-25.

Chmielak, A. (2000). Trwały i zrównoważony rozwój a zmiany instytucjonalne. Ekonomia i Środowisko, 1,7-23.

Czubała, A. (2001). Dystrybucja produktów. PWE, Warszawa.

Doležalova, H., Pícha, K., Navratil, J. (2009). Analysis of the organic food marketing - chain store companies (South Bohemia). Agric. Econ. - Czech, 55(9), 446-458.

Jones, P., Clarke-Hill, C., Shears, P., Hillier, D. (2001). Case Study. Retailing Organic Foods. British Food Journal, 103(5), 359-365.

Łuczka-Bakuła, W, Smoluk-Sikorska, J. (2011). Quality as a criterion for purchasing decisions of the organic food consumers. Zeszyty Naukowe Uniwersytetu Ekonomicznego w Poznaniu, 216, 214-222.

Łuczka-Bakuła, W. (2007). Rynek żywności ekologicznej. Wyznaczniki i uwarunkowania rozwoju. PWE, Warszawa.

Łuczka-Bakuła, W., Smoluk-Sikorska, J. (2010). Poziom cen produktów ekologicznych w handlu detalicznym. Zeszyty Naukowe Wyższej Szkoły Handlu i Ustug, 20, 39-48.

Meredith, S., Willer, H. (2016). Organic in Europe. Prospects and Developments 2016. Brussels: IFOAM, FiBL.

Pilarczyk, B. (1999). Promocja i reklama. In: H. Mruk, B. Pilarczyk, B. Sojkin, H. Szulce (eds.) Postawy marketingu. Wyd. AE w Poznaniu.

Pilarczyk, B., Nestorowicz, R. (2010). Marketing ekologicznych produktów żywnościowych. Wolters Kluwer, Warszawa

Richter, T., Hempfling, G. (2003). Supermarktketten und ihre Stellung im Bio-Markt, FIBL-Arbeitspapier 2003. Accessed 16 January 2015 from: http://orgprints.org/2632/01/richter-2003-FiBL-SupermarkstudieBiofach.pdf.

Rogoda, B. (2003). Decyzje cenowe przedsiębiorstw: pomocnicze materiały dydaktyczne. Wyd. UE w Krakowie.

Santucci, F.M., Marino, D., Schifani, G., Zanoli, R. (1999). The marketing of organic food in Italy. Medit, 4, 8-14.

Szczepankiewicz, W. (2004). Organizacja źródeł zaopatrzenia i rola handlu detalicznego w kanałach rynku. In: J. Szumilak (ed.) Handel detaliczny. Funkcjonowanie i kierunki rozwoju. Oficyna Ekonomiczna, Kraków.

Szulce, H. (1998). Struktury i strategie w handlu. PWE Warszawa.

Wier, M., Calverly, C. (2002). Market potential for organic foods in Europe. British Food Journal, 104(1), 45-62.

Willer, H., Lernoud, J. (eds.) (2017). The world of organic agriculture. Statistics and emerging trends 2017. Frick: FiBL.

Żakowska-Biemans, S., Gutkowska, K. (2003). Rynek żywności ekologicznej w Polsce i w krajach Unii Europejskiej. Wyd. SGGW, Warszawa.

Zdrojewska, I. (2017). Raport o stanie rolnictwa ekologicznego w Polsce 2015-2016. IJHARS, Warszawa. 